\title{
ANALYSIS OF YIELD AND ITS COMPONENTS USING FIVE PARAMETERS FOR THREE BREAD WHEAT CROSSES
}

\author{
WAFAA A. EL-AWADY \\ Wheat Research Dept., Field Crops Research Institute, ARC, Giza.
}

(Manuscript received 10 April 2011)

\begin{abstract}
This investigation was carried out at Etay El- Barod research station. Five populations $\left(P_{1}, P_{2}, F_{1}, F_{2}\right.$ and $\left.F_{3}\right)$ for three cross namely Sakha $93 \times$ Line32, Giza $168 \times$ Line 42 and Sakha $93 \times$ Giza 168 were used in this investigation to study the genetic behavior of yield and its components. Significant positive heterotic effects were obtained for most of the characters studied in the $F_{1}$ generations. However, significant negative heterotic effects were found for all other characters except for no.of spikes/plant in the first and third crosses, and no.of spikes/plant , and grain yield/plant, in the second cross. Inbreeding depression estimates were found for kernels weight in the first cross, no.of kernels/spikes and kernels weight in the second cross, no.of spike/plant and grain yield/plant in the third one. The (additive, and additive $x$ dominance )gene effects were significant for number of spikes/plant, number of kernels/spike and grain yield/plant in the second cross. Dominance gene effect (h) was significantly positive for number of kernels/spike and grain yield/plant in the three crosses. Significance of these components indicated that, both additive and dominance gene effects are important in the inheritance of these characters. In addition, dominance and epistasis were found to be significant for most of the studied attributes. Moreover, high to medium values of heritability estimates were associated with high and moderate expected and actual gain in most studied characters. These obtained results prove that selection for the studied characters could be used in the early generations but would be more effective if postponed to late ones.
\end{abstract}

\section{INTRODUCTION}

Wheat (Triticum aestivum L.) is one of most important and strategic cereal crop allover the world. It provides over $20 \%$ of calories and protein for human nutrition, and is staple food for over $35 \%$ of the world's population in more than 40 countries. In Egypt, wheat is the main winter cereal crop used as a staple food for urban as well as rural societies and the major source of straw for animal feed (Shehab El- Din, 1993). However, total wheat consumption has increased drastically due to over population growth by $2.5 \%$ per year. Egypt imports about $45 \%$ of its wheat requirements. This, reflects the size of the 
problem and the efforts needed to increase wheat production. Thus increasing wheat production per unit area appears to be one of the important factors for narrowing the gap between wheat production and consumption. Wheat breeders in Egypt are looking for sources of genetic improvements in grain yield and its components and other agronomic characters. The Egyptian wheat cultivars have some wheat narrow genetic background. Selection among these cultivars for increasing grain yield and its components would not be very effective. Hybridization between the Egyptian wheat cultivars and exotic materials may be a source for to increasing genetic variability among breeding materials.

Genetic diversity among crossed parents enables the breeder to develop, through genetic recombination, heritable variability upon which selection can be practiced. Knowledge of the genetic relationship among parents is essential to breeders for planning crosses that may lead to developing more promising lines. Crumpack and Allard (1962) indicated that efficiency in breeding of selfpollinating crops depends, first, on accurate identification of hybrid combinations that have the potentiality of producing maximum improvements and second, on identifying in early segregating generations, the superior lines among the progeny of the most promising hybrids. Therefore, information on the genetics of breeding materials could ensure long-term selection gains and more genetic improvements.

AI- Kaddoussi et. al. (1994) reported that, dominance component of gene action played an important role in the genetic control for, number of spikes/plant, number of kernels/spike, kernel weight and grain yield/plant. Therefore, maximum progress in improving a character would be expected with a carefully designed pedigree selection program when the additive gene action is the main component.

EI- Hosary et. al. ( 2000) found that, grain yield and its components in a diallel cross mating among eight parents, were controlled by both, additive and non-additive gene effects. In addition, concerning the heritability as narrow sense, . El-Sayed ( 2004 ) and Abdel-Nour et. al. ( 2005 ) reported that heritability estimates for yield and its components were medium to high.

This work was conducted to study the genetic variance, gene action, heritability and comparison between actual and expected genetic gain of three bread wheat cresses derived from four parental bread genotypes using five populations of each cross. 


\section{MATERIALS AND METHODS}

Four, wieldy diversed, bread wheat parents were chosen to form three crosses, viz. (1) Sakha 93x Line 23, Giza 168x Line42 and Sakha 93 x Giza 168. Table 1. Names, pedigree and origin of the parental cultivars and lines

\begin{tabular}{|l|l|c|}
\hline Cultivar & \multicolumn{1}{|c|}{ Pedigree } & Origin \\
\hline SaKha 93 & $\begin{array}{l}\text { Sakha 92/TR8 10328 } \\
\text { S8871-1s-2s 13-Os. }\end{array}$ & EGYPT \\
\hline Giza 168 & $\begin{array}{l}\text { MRI/BUG/SEPI } \\
\text { CM933046-8M-OY-OM-2Y-O3-OGZ. }\end{array}$ & EGYPT \\
\hline Line 23 & $\begin{array}{l}\text { OASIS / 2* BOPL95 } \\
\text { CMBW91MO2624M-OTOPY-010Y-010M-010Y-0ET }\end{array}$ & CIMMYT \\
\hline Line42 & $\begin{array}{l}\text { 2V879.C8.11/G110//V979/3/Star } \\
\text { CMBW91M02624M-0TOPY-16M-010Y-ET }\end{array}$ & CIMMYT \\
\hline
\end{tabular}

The experimental work was carried out at Ety El Barod Research Station, El - Behyra, Egypt, during four successive seasons. In 2006/2007,the parental genotypes were crossed to obtain $F_{1}$ seeds. In the second season 2007/2008, the hybrid seed of the three crosses were sown to give the $F_{1}$ plants. These plants were selfed to produce $F_{2}$ and $F_{3}$ seeds. Moreover, the same crosses were made to have enough $F_{1}$ seeds. The new hybrid seed and part of seeds obtained from $F_{1}$ selfed plants ( $F_{2}$ seeds) were kept in refrigerator to the final experiment . In 2008/2009 the $F_{1}$ and $F_{2}$ plants were selfed to produce $F_{2}$ and $F_{3}$ seeds, respectively.

In the fourth season $(2009 / 2010)$ the obtained seeds of the five populations $\left(P_{1}, P_{2}, F_{1}, F_{2}\right.$ and $\left.F_{3}\right)$ of the three crosses were evaluated using randomized complete block design with three replications. Rows were $4 \mathrm{~m}$ long, spaces between rows were $20 \mathrm{~cm}$, plants within rows $10 \mathrm{~cm}$. Two rows devoted for each parent and $F_{1}$ progenies , 20 rows for $F_{2}$ generation and 5 rows for $F_{3}$ families for each cross. Data were recorded on individual guarded plants for number of spikes/plant, number of kernels/spike, 100 kernel weight $(\mathrm{g})$ and grain yield/plant $(g)$. 
Various biometrical parameters in this study would only be calculated if the $F_{2}$ genetic variance was significant. In this concern, $F_{2}$ genetic variance were significant. Heterosis $\%$ was expressed as percentage deviation of $F_{1}$ mean performance from better parent values (heterobeltiosis).

The estimates of mean effect parameter $(m)$, additive-additive $x$ dominance $\left(\mathrm{d}^{*}\right)$, dominance $(\mathrm{h})$, dominance $\mathrm{x}$ dominance $(\mathrm{I})$ and additive $x$ additive (i) were obtained by five parameters model illustrated by Hayman model according to Singh and Chaudhary ( 1985 ).

Heritabiliiy in both broad and narrow senses were calculated according to Mather ( 1949 ) and parent offspring regression according to Sakai ( 1960 ). On the other hand, the expected and actual genetic advance ( $\mathrm{Ag}$ ) was computed according to Johansen et. al. (1955). Similarly, the genetic gain percentage of the $F_{2}$ and $F_{3}$ mean performance ( $\mathrm{Ag} \%$ ) was estimated using the method of Miller et a/ ( 1958 ).

\section{RESULTS AND DISCUSSION}

The choice of the parents to be crossed in breeding programs are the most important problem facing the breeder .If the parents are precisely selected, the desired recombination will be found in the segregated generations (Mahrous,1998). The parental differences in response to their genetic background were found to be significant in most characters under investigation. The $F_{2}$ populations were also significant for all studied characters in the three crosses studied.

Means and variances of five populations i.e., (P1, P2, F1, F2 and F3) for the studied characters in three crosses are presented in Table (2).

Heterosis, inbreeding depression percentage and different gene action for the four studied characters are given in Table (3). In self pollinated crops such as wheat, plant breeders have been investigated the possibility of developing hybrid cultivars. The feasibility of growing hybrid cultivars depends on the economic production of large quantitative of hybrid seeds and significant superiority in yield as well as best performance of hybrids compared to the current commercial cultivars (Mahrous, 1998 ). On the other hand, heterosis over better parent may be useful in identifying the best hybrid combinations but these hybrids can be immense practical value if they involve the best cultivar of the area (Prasad et.al., 1998).

Significant positive heterotic effect was found for all characters except for number of kernels/spike in the third and second crosses and for number 
of spikes/plant in the first cross . By contrast, significant negative heterotic effects were found for number of spikes/plant in the first cross. Similarly trends were reported by El-Hosary et. al. (2000), El Sayed (2004), AbdolNour, Nadya and Moshref( 2006 ).

Number of spikes/plant, number of kernels/spike and 100 kernel weight are the main components of grain yield/plant. Hence, heterotic, increase, if found in one or more of these attributes with other being constant would load to favorable yield increase in a hybrid. The lack of significance in heterosis for number of spikes/plant in the first cross could be due to the lower magnitude of the non - additive gene action. These results are In agreement with EI-Rassas and Mitkess (1985).

The pronounced of heterotic effect showed that the first cross had the highest values for number of spikes/plant (24.32), number values for kernels/spike (89.95) and grain yield/plant(69.95 gm). Thus, this cross (Sakha $93 \times$ line 23) may that in consideration in breeding program for improvement the yield potentiality.

Inbreeding depression were obtained in the first and second crosses for number of spikes/plant and grain yield/plant in two out of the three crosses for number of kernels spike and in one out of the three crosses for 100-kernel weight. This is valid result, since the expression of heterosis in the $\mathrm{F} 1$ may be followed by reduction in F2 performance. The obtained results for most crosses were in harmony with those obtained by Khalifa et. al. (1997).

Significant heterosis and insignificant inbreeding depression were obtained for no. of spikes/plant, kernel weight in the first and third crosses. Moreover, significant positive heterosis and significant negative inbreeding depression were detected. The contradiction between heterosis and inbreeding depression estimates could be due to the presence of linkage between genes in these materials (Van der Veen 1959). 
Table 2. Means $(\bar{X})$ and variances $\left(\mathrm{s}^{2}\right)$ for the studied characters using the five populations for the three bread wheat crosses.

\begin{tabular}{|c|c|c|c|c|c|c|}
\hline \multirow{2}{*}{$\begin{array}{c}\text { Charac } \\
\text { ters }\end{array}$} & \multirow{2}{*}{ parameters } & \multicolumn{5}{|c|}{ Sakha 93 xline 23} \\
\hline & & $P_{1}$ & $P_{2}$ & $\mathrm{~F}_{1}$ & $\mathrm{~F}_{2}$ & $\mathrm{~F}_{3}$ \\
\hline \multirow{2}{*}{$\begin{array}{l}\text { No.of } \\
\text { spikes/ } \\
\text { plant }\end{array}$} & * & 21.95 & 25.22 & 24.32 & 20.95 & 23.43 \\
\hline & $5^{2}$ & 6.22 & 7.24 & 6.32 & 23.98 & 22.31 \\
\hline \multirow{2}{*}{$\begin{array}{l}\text { No.of } \\
\text { kernel } \\
\text { s/spike }\end{array}$} & $x$ & 72.90 & 82.22 & 89.95 & 69.93 & 65.22 \\
\hline & $S^{2}$ & 11.22 & 4.55 & 19.27 & 187.52 & 166.55 \\
\hline \multirow{2}{*}{$\begin{array}{c}100- \\
\text { kernel } \\
\text { weig } \\
(\mathrm{g})\end{array}$} & $\mathrm{x}$ & 4.36 & 4.55 & 5.12 & 5.33 & 4.89 \\
\hline & $S^{2}$ & 0.03 & 0.05 & 0.09 & 0.44 & 0.23 \\
\hline \multirow{2}{*}{$\begin{array}{c}\text { Grain } \\
\text { yield/ } \\
\text { Plant (g) }\end{array}$} & $\underline{x}$ & 57.95 & 66.20 & 69.95 & 64.31 & 63.22 \\
\hline & $S^{2}$ & 13.35 & 19.42 & 22.41 & 439.21 & 285.32 \\
\hline \multicolumn{7}{|c|}{ Giza 168 x Line 42} \\
\hline \multirow{2}{*}{$\begin{array}{l}\text { No.of } \\
\text { spikes/ } \\
\text { plant }\end{array}$} & $\underline{x}$ & 20.98 & 20.32 & 23.11 & 20.06 & 18.96 \\
\hline & $S^{2}$ & 5.81 & 4.22 & 5.23 & 36.20 & 25.21 \\
\hline \multirow{2}{*}{$\begin{array}{l}\text { No.of } \\
\text { kernel } \\
\text { s/spike }\end{array}$} & $-x$ & 81.23 & 72.18 & 75.32 & 73.18 & 69.57 \\
\hline & $S^{2}$ & 22.18 & 18.43 & 20.16 & 216.50 & 186.16 \\
\hline \multirow{2}{*}{$\begin{array}{l}100- \\
\text { kernel } \\
\text { weight } \\
(\mathrm{g})\end{array}$} & $\mathrm{x}$ & 4.48 & 5.04 & 5.27 & 5.17 & 5.68 \\
\hline & $S^{2}$ & 0.04 & 0.02 & 0.03 & 0.23 & 0.12 \\
\hline \multirow{2}{*}{$\begin{array}{c}\text { Grain } \\
\text { yield/ } \\
\text { Plant }(\mathrm{g}) \\
\end{array}$} & $x$ & 56.23 & 53.30 & 63.52 & 59.34 & 55.31 \\
\hline & $S^{2}$ & 19.20 & 18.82 & 17.22 & 285.52 & 171.30 \\
\hline \multicolumn{7}{|c|}{ Sakha 93x Giza 168} \\
\hline \multirow{2}{*}{$\begin{array}{l}\text { No.of } \\
\text { spikes/ } \\
\text { plant }\end{array}$} & $x$ & 21.95 & 20.98 & 22.57 & 21.45 & 19.45 \\
\hline & S2 & 6.22 & 5.81 & 4.46 & 35.12 & 24.11 \\
\hline \multirow{2}{*}{$\begin{array}{l}\text { No.of } \\
\text { kernel } \\
\text { s/spike }\end{array}$} & $x$ & 72.90 & 81.23 & 73.22 & 67.78 & 65.22 \\
\hline & $\mathrm{S} 2$ & 11.22 & 22.18 & 17.95 & 248.99 & 174.9 \\
\hline \multirow{2}{*}{$\begin{array}{l}100- \\
\text { kernel } \\
\text { weight } \\
(\mathrm{g})\end{array}$} & $\mathrm{x}$ & 4.36 & 4.48 & 5.02 & 5.21 & 5.69 \\
\hline & S2 & 0.03 & 0.04 & 0.04 & 0.26 & 0.15 \\
\hline \multirow{2}{*}{$\begin{array}{c}\text { Grain } \\
\text { yield/ } \\
\text { Plant (g) }\end{array}$} & $\mathrm{x}$ & 57.95 & 56.23 & 61.22 & 59.20 & 56.22 \\
\hline & $\mathrm{S} 2$ & 13.35 & 19.20 & 17.43 & 281.98 & 187.06 \\
\hline
\end{tabular}


Table 3. Heterosis, inbreeding depression and gene action parameters for the three bread wheat crosses.

\begin{tabular}{|c|c|c|c|c|c|c|c|c|}
\hline \multirow{2}{*}{ Characters } & & \multirow{2}{*}{$\begin{array}{r}\text { Heterosi\% } \\
\text { over B.P }\end{array}$} & \multirow{2}{*}{$\begin{array}{c}\text { Inbreeding } \\
\text { Depression } \\
\%\end{array}$} & \multicolumn{5}{|c|}{ Gene action parameters } \\
\hline & & & & $\mathrm{m}$ & $d^{*}$ & $\mathrm{~h}$ & I & $\mathrm{i}$ \\
\hline No. of & 1 & -3.57 & $13.86 * *$ & $20.95 *$ & $-1.64 * *$ & -4.36 & $-22.2^{* *}$ & $-15.6^{*}$ \\
\hline Spike/ & 2 & $10.15^{* *}$ & $15.20 * *$ & $20.06 *$ & $0.33 * *$ & 4.97 & 2.27 & $3.62 *$ \\
\hline Plant & 3 & 2.82 & 4.96 & 21.45 & 0.49 & 6.08 & -7.68 & 5.95* \\
\hline No.of & 1 & $9.40 * *$ & $22.26 * *$ & $69.93 *$ & $-4.66 * *$ & $24.8 * *$ & $28.2 * *$ & $3.65^{* *}$ \\
\hline kernels & 2 & 0.07 & 2.84 & $73.18^{*}$ & $4.53 * *$ & $11.05 *$ & $-28.8 * *$ & $5.79 * *$ \\
\hline spike & 3 & $9.86 * *$ & $7.43 *$ & 67.78 & -4.17 & $10.45 *$ & 0.85 & 5.97 \\
\hline $100-$ & 1 & $12.53 * *$ & -0.041 & $5.33 *$ & -0.095 & $1.03 *$ & $25.9 * *$ & -7.05 \\
\hline Kernels weight & 2 & 4.56 & 1.93 & $5.17 *$ & $-0.28 *$ & $2.74 * *$ & $2.99 * *$ & -0.34 \\
\hline & 3 & $12.05^{* *}$ & $-3.78 *$ & 5.21 & -0.06 & -1.76 & 2.053 & -0.367 \\
\hline Grain & 1 & 5.66 & $8.03 * *$ & $64.33 *$ & $-4.13 * *$ & $38.3 * *$ & $9.07 * *$ & 6.42 \\
\hline yield/ & 2 & $12.6 * *$ & $6.58 *$ & $59.34 *$ & $10.47 *$ & $13.5^{* *}$ & -10.35 & 7.71 \\
\hline plant & 3 & $5.64 * *$ & 3.30 & 59.20 & 0.86 & $9.29 *$ & 2.05 & 3.74 \\
\hline
\end{tabular}

Nature of gene action was determined using the five parameters (Table 3). The estimated mean effect of $F 2(m)$, which reflects the contribution due to over all mean plus the locus effects and interactions of the fixed loci, was found to be highly significant. The additive gene effect, (d)* was significantly positive for number of spikes/plant, number of kernels/spike and grain yield/plant in the second cross. On the other hand, (d*) was negatively significant for, number of spikes/plant, and grain yield/plant in the firs cross and for 100 kernel weight in the second one. This results suggested that, the potential for obtaining further improvement for the formor characters (i.e that showed positive and significant values) by using pedigree selection. These results were greatly agreed with those obtained by El Hosary et. al. ( 2000 ). El Sayed (2004), Abdel-Nour, Nadya and Moshref (2006).

Dominance gene effect $(h)$ was significantly positive for number ofkernels/spike and grain yield/plant in the three studied crosses, and for 100 kernel weight in the first and second crosses.

Significance of these components indicated that, both additive and dominance gene effects are important in the inheritance of these characters. 
Hence, selection of the desired characters may be practiced in the early generations but may be more effective in latest ones, Shehab El-Din ( 1993 ).

Dominance $\mathrm{x}$ dominance (I)type of gene action was significantly positive for number of kernel/spike,100 kernel weight and grain yield/plant in the first cross and 100 kernel weight in the second cross.

A significant additive $x$ additive type of epistasis (i) was detected for number of kernels/spike in the first and second crosses and for number of spikes/plant in second and third ones.

The important roles of both additive and non - additive gene action in certain studied characters indicated that, selection procedures based on the accumulation of additive effects may be very successful for improving these characters. Similar approaches were reported by AlKaddoussi et. al. (1994), El hosary et. al. (2000).

Heritability in both broad and narrow senses, and between generations (parent off- spring regression ) are presented in Table (4). High heritability values in broad sense were detected for all studied characters .

High to moderate estimates of narrow sense heritability and parent off- spring regression was found for all studied characters. The difference in magnitude of both narrow sense and parent off spring regression heritability estimates for all studied characters may be assure the existence of both, additive and non - additive gene effects in the inheritance of these characters. Similarly, El Sayed (2004), Abdel-Nour Nadia et. al. (2005 ) reported these conclusions.

Also, expected genetic gain and actual gain for all studied characters are shown in Table (4). The expected genetic advance ( $\mathrm{Ag} \%$ of $\mathrm{F} 2$ ) and actual genetic advance ( $\mathrm{Ag} \%$ of $\mathrm{F} 3$ ) ranged from moderate to high values for all studied characters except for, kernels weight in the three studied crosses. These results indicated the possibility of practicing selection in early generations to be assure that these characters and hence, selecting high yielding genotypes. Dixit et. al. (1970) pointed out that, high heritability is not always associated with high genetic advance, but in order to make effective selection, high heritability should be associated with high genetic gain.

Generally, the most biometrical parameters resulted from the first and second crosses were higher in magnitude than those obtained from the third one. Consequently, it could be concluded that the crosses (Sakha 93 x line23) 
and (Giza $168 \times$ line 42) would be of interest in a breeding program for genetic improvement of wheat.

Table 4. Heritability and expected versus actual gain for all studied characters in three crosses of bread wheat.

\begin{tabular}{|c|c|c|c|c|c|c|c|c|}
\hline \multirow[b]{2}{*}{ Characters } & \multirow[b]{2}{*}{ Crosses } & \multicolumn{3}{|c|}{ Heritability\% } & \multicolumn{2}{|c|}{ Expected gain } & \multicolumn{2}{|c|}{ Actual gain } \\
\hline & & $\begin{array}{l}\text { Broad } \\
\text { sense }\end{array}$ & $\begin{array}{l}\text { Narrow } \\
\text { sense }\end{array}$ & $\begin{array}{l}\text { Parent off- } \\
\text { spring } \\
\text { regression }\end{array}$ & $\mathrm{Ag}$ & $\%$ of $F_{2}$ & $\mathrm{Ag}$ & $\%$ ofF $_{3}$ \\
\hline \multirow{3}{*}{$\begin{array}{l}\text { No.of } \\
\text { Spikes/plant }\end{array}$} & 1 & 77.63 & 74.58 & 48.74 & 1.97 & 7.33 & 4.77 & 20.35 \\
\hline & 2 & 81.48 & 61.22 & 73.66 & 7.55 & 31.55 & 6.48 & 38.09 \\
\hline & 3 & 84.5 & 58.50 & 72.30 & 7.13 & 34.23 & 7.23 & 39.92 \\
\hline \multirow{3}{*}{$\begin{array}{l}\text { No.of Kernel } \\
\text { s/spike }\end{array}$} & 1 & 91.23 & 62.33 & 58.65 & 4.99 & 7.97 & 16.29 & 21.98 \\
\hline & 2 & 94.36 & 65.36 & 79.33 & 22.55 & 29.66 & 23.06 & 32.88 \\
\hline & 3 & 91.70 & 63.20 & 78.30 & 21.56 & 31.4 & 20.96 & 31.99 \\
\hline \multirow{3}{*}{$\begin{array}{l}\text { 100-kernel } \\
\text { Weight }\end{array}$} & 1 & 86.56 & 83.65 & 84.56 & 1.07 & 0.89 & 0.89 & 17.69 \\
\hline & 2 & 82.95 & 79.69 & 85.12 & 1.23 & 17.33 & 0.67 & 10.85 \\
\hline & 3 & 85.80 & 80.50 & 82.80 & 0.83 & 16.41 & 0.66 & 11.50 \\
\hline \multirow{3}{*}{$\begin{array}{l}\text { Grain } \\
\text { yield/plant }\end{array}$} & 1 & 91.55 & 78.82 & 88.23 & 35.26 & 54.32 & 27.66 & 47.44 \\
\hline & 2 & 93.22 & 77.35 & 87.55 & 28.97 & 47.11 & 24.11 & 43.17 \\
\hline & 3 & 94.22 & 76.40 & 85.20 & 30.22 & 46.00 & 23.55 & 42.97 \\
\hline
\end{tabular}

\section{REFERENCES}

1. Abdel-Nour, A. Nadya and M. Kh. Moshref. 2006. Gene effects and variances in three wheat crosses using the five parameters model. Egypt. J. Plant Bread. 10(1): 305-318.

2. Abdel Nour, Nadya, A. R., H. A. Ashoush and Sabah H. Abo Elea. 2005. Diallel crosses analysis for yield and yield components in bread wheat. J. Agric. Sci Mansoura Univ., 30(1): 5725-5738.

3. AI-Kaddoussi, A. R., M. M. Eissa and S. M. Salama. 1994. Estimates of Genetic variance for yield and its components in wheat (Triticum aestivum L.). Zagazig J. Agric. Ros. 21 (2)'355-366.

4. Crumpacker, D. W. and R. W. Allard. 1962. A diallel cross analysis of heading date in wheat. Hilgardi, 32, 275-277.

5. Dixit, P. K., P. O. Sexena, and LK. Bhatia. 1970. Estimation of genotypic variability of some quantitative characters in groundut Indian J. Agric. Sci. 40:197-201, 
6. EI-Hosary, A. A., M. E. Raid, Nagwa A. Rady and Manai A. Hassan. 2000. Heterosis and combining ability in durum wheat. Proc. 9thconf, Agron Minufiya Univ., :101-117.

7. El- Sayed, E. A. M. 2004. A diallel cross analysis for some qualitative characters in bread wheat (Triticum astivum L ).Egypt J. Agric . Res., 82(4): $1665-1679$.

8. EI-Rassas, H. N. and R. A. Mitkees. 1985. Heterosis and combining ability in bread wheat (Triticum astivum L ). Annals of Agric. Sci., Moshtohor. 23(2): $698-711$

9. Johansen, H. W., H. F. Robinson and R. E. Comstock. 1955. Estimates of genetic and environmental variability in soybeans. Agron. J. 47:314.

10. Mahrous. A. M. 1998. Estimates of heterosis and combining ability for some quantitative characters in bread wheat. Minufiya J. Agric. Res.,Vol 23 No. 4:929-947.

11. Mather, K. 1949. Biometrical Genetics. Dover Publication inc., London.

12. Miller, P. A., J. C. Williams, H. F. Robinson and R. E. Comstock.1958. Estimates of genotypes and environmental variances in upland cotton and their implications in selection. Agron. J. 50:126-181.

13. Prasad. K. D., M.Fhaque and D. K. Ganguli. 1988. Heterosis studies for yield and its components in bread wheat (Triticum aesiivum L). Indian J. Genet., 58: 97-100.

14. Sakai, K. i, 1960. Scientific basis of plant breeding. Lectures given at the Faculty of Agric., Cairo Univ. and Alex. Univ,

15. Shehab El-Din, T. M. 1993. Response of two spring wheat cultivars (Triticum aostivum L. em. Thell) to ten, seeding rates in sandy soil. J.Agric. Sci. Mansoura Univ. 18:2235-2240.

16. Singh, R. K. and B. D. Chaudhary. 1985. Biometrical Methods in Quantitative Gentic Analysis . Kalyani Puplisher, New Delhe, Ludhinana, India.

17. Van der Veen, J. H. 1959. Test of non-allelic interaction and linkage for quantitative characters in generations derived from two diploid pure lines. Genetica, 30:201. 
تحليل المحصول ومكوناته باستخذام نموذج العشائر الخمسة لثلاثة هجن من قمح الخبز

$$
\begin{aligned}
& \text { وفاء عبد الحميد العوضى } \\
& \text { قسم بحوث القهح - معرج بحوث المحاصيل الحقلية - مركز البحوث الزراعية }
\end{aligned}
$$

أجرى هذا البحث فى محطة بحوث الزر اعية فى ايتاى البارود محافظة البحيرة جمهورية

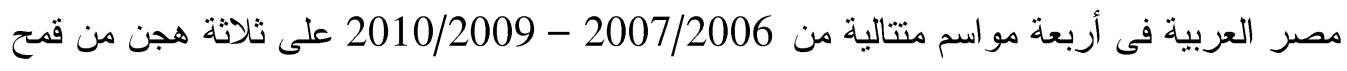

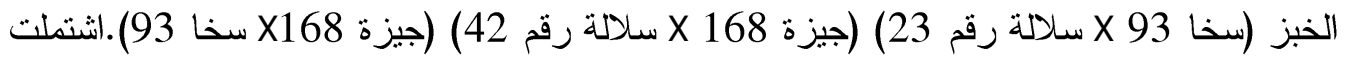
الدر اسة على كل من الأبوين و الأجيال الأول و الثاني و الثالث لكل هجين وكانت النتائج كما يلى:

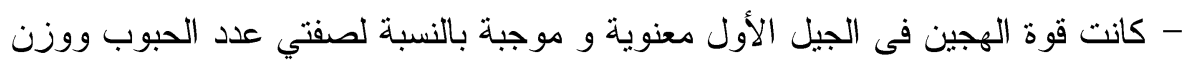

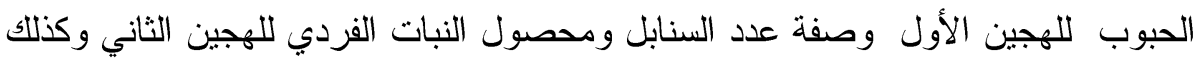
عدد السنابل ووزن الحبوب ومحصول النبات الفردي للهجين الثالث. - كان تأثير التربة الداخلية فى الجيل الثانى موجبة ومعنوية فى الهجنين الأول لصفة عدول السنابل و عدد الحبوب و ومحصول النبات الفردي وصفة و عدد الحبوب للاجين الثالث - أظهرت التاثيرات الور اثية المضيفة وكلل الفعل الجيني غير المضيف دور الهاما في وراثة وعندئ معظم الصفات

- أظهرت كفاءة التوريث بمعناها الو اسع قيما عالية الى متوسطة وبمعناها الضيق قيماً

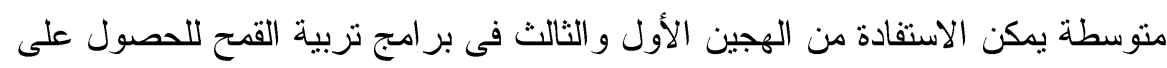
سلالات متفوقة فى المحصول النتائج المتحصل عليها تدل على ان الانتخاب فى الأجيال الانعز الية المبكرة قد يكون مفيدا ولكن سوف يكون أكثر كفاءة إذا تم تأجيله الى الأجيال

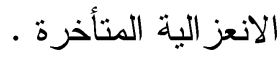

